\title{
EXPORT OF INDONESIAN MSES AND THE ROLE OF PARTNERSHIP
}

\section{Tulus T. H. Tambunan*}

*Faculty of Economics and Business, Universitas Trisakti, Indonesia

\begin{abstract}
There have been many theoretical and empirical studies on the main factors 'determining the ability of micro and small enterprises (MSES) in developing countries to export. However, so far, there has been very little attention to the role of partnerships between MSEs and large enterprises (LES), government agencies, banks, or others. The purpose of this study is to fill this gap in the existing literature with the case of MSEs in the manufacturing industry (called micro and small industries or MSIs) in Indonesia. It is a descriptive study that analyses secondary data from a national survey conducted by the Indonesia Central Statistics Agency in 2019. It reveals that the most common form of partnership is marketing partnership. The finding may suggest that MSIs that have partnerships with LEs or others are more able to export than their counterparts without partnerships.
\end{abstract}

Keywords: MSMEs, MSEs, MSIs, Partnership

JEL: M31, L25, D22

\author{
ARTICLE INFO \\ Received: July $30^{\text {th }}, 2021$ \\ Revised: October $29^{\text {th }}, 2021$ \\ Accepted: October 31 ${ }^{\text {st }}, 2021$ \\ Online: November 25 $5^{\text {th }}, 2021$ \\ *Correspondence: \\ Tulus T. H. Tambunan \\ E-mail: \\ ttambunan56@yahoo.com
}

To cite this document: Tambunan, T. T. H. (2021). Export of Indonesian MSEs and The Role of Partnership. JDE (Journal of Developing Economies), 6(2), 235-252

\section{Introduction}

As in many other developing countries, micro, small and medium enterprises (MSMEs) play a significant role in economic development in Indonesia. These enterprises are the main drivers of national economic activities, contributing to the formation of Indonesia's gross domestic product above $50 \%$. They are very numerous, reaching $99 \%$ of the number of companies of all sizes and accounting for $92 \%$ of job creation. Especially micro and small enterprises (MSEs) are the primary source of employment opportunities for low skilled workers and business opportunities for married women from poor households in rural areas. In Indonesia, many married women from poor households own small businesses such as food stalls, small shops that sell simple items of daily necessities for villagers, or handicrafts from bamboo, rattan or wood. They do such activities solely to increase family income (Tambunan, 2017).

Apart from their contributions to employment generation and gross domestic product (GDP) formation, MSMEs are also expected to contribute to export growth. However, available data and literature suggest that MSMEs, especially MSEs in Indonesia, cannot participate in export compared to their larger counterparts. Based on national data provided by the Minister of Cooperatives \& UKM, the share of MSME exports in Indonesia's total exports is always very small. In 2007 the share was around 17.7\% and dropped to 15.7\% in 2019 (Figure 1). 


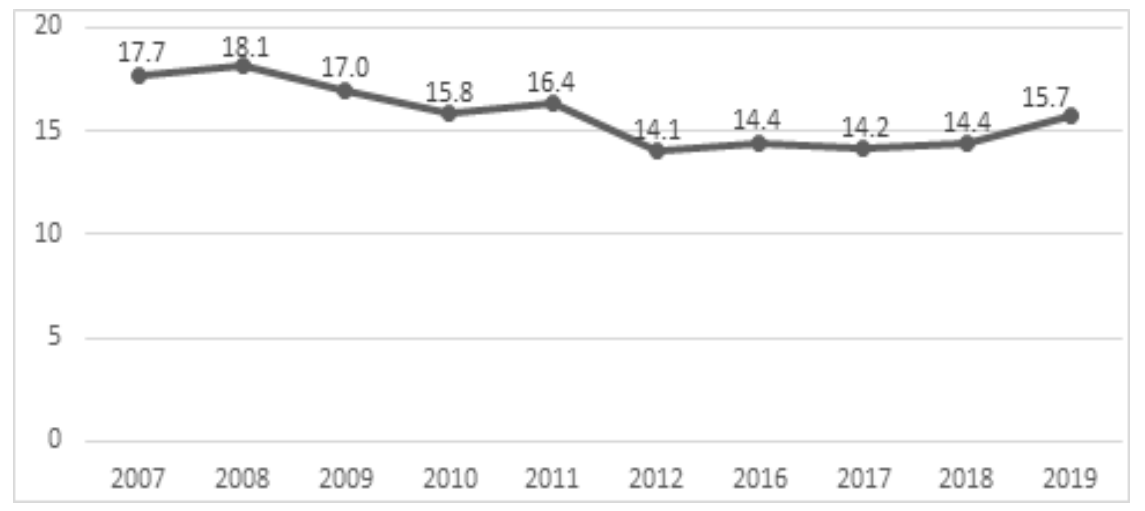

Figure 1: Export development of Indonesian MSMEs, 2007-2019 (\% of Total Exports) Source: Menegkop \& UKM (online)

Even the export performance of Indonesia's MSMEs is much weaker than that of their counterparts in neighbouring countries. Based on many sources, Malaysia MSMEs accounted for nearly $19.0 \%$, Vietnam $20.0 \%$, the Philippines $25.0 \%$ and Thailand nearly $30.0 \%$ (e.g. UN-ESCAP, 2010; Wignaraja, 2012; ADB, 2015; ASEAN, 2015a; ASEAN, 2015b; OSMEP (2015); Tambunan, 2015a,b; SME Corp Malaysia, 2015; Yoshino \& Wignaraja, 2015; APEC, 2002). This regional data also confirms that LEs contributed to most exports in the region.

Maybe because much evidence suggests that in comparison with LEs, MSMEs are relatively less able to do export, over the past several decades, MSMEs involved in export have been extensively investigated as Leonidou (2004), Leonidou et al. (2007), Arteaga-Ortiz \& Fernández-Ortiz (2010), Mpunga (2016), and Alam (2017). Breckova (2018) have explored barriers and stimuli for MSMEs' export activities. While such as Jones \& Coviello (2005) have investigated the main determinants, the underlying processes and the effects on MSMEs' performance of their decisions to set up international activities. From the results of all existing studies, both in developing and developed countries, a list of internal and external factors that have affected the ability of MSMEs to export directly can be made. These factors include lack of funding sources, limited knowledge, especially regarding how to export, lack of networks, international market information, and procedural (bureaucratic) and governmental (institutional) barriers.

Although export growth is influenced by many factors, directly and indirectly, and from both sides, market demand and supply, this research focuses on the importance of partnership or network with large enterprises (LEs), financial institutions, and business associations, universities, etc. So far, theoretical as well as empirical studies on this issue is still limited which include such as Revindo et al. (2019), Petrit et al. (2012), and Shepherd \& Duve (2013) who emphasize that among many crucial MSMEs' export determinant factors is also network relationships including with foreign direct investment-based companies.

There are two reasons to focus on this issue. First, empirical research on the role of partnership in developing MSMEs' exports is still scarce, if not to say nothing at all. Second, the Indonesian government has urged MSMEs, especially MSEs, to collaborate with LEs in subcontracting arrangements. The government has long realized that having production or marketing linkages with LEs can greatly help MSEs to increase their production and marketing, including export capabilities. The government requires all state-owned companies (SOCs) to support MSMEs in their sectors through partnership arrangements. Even in specific sectors, foreign direct investment-based companies must have production linkages with local MSMEs. It is a requirement for all foreign companies to operate in these sectors in the country. 
Generally speaking, a partnership can be defined as an arrangement where parties, known as business partners, agree to cooperate to advance their mutual interests. So partnership can also be seen as "formal," contractual relationships among organizations or parties: strategic alliances, buyer-supplier contracts, joint ventures etc. But in the case of MSMEs in Indonesia, the meaning or purpose of the partnership is more to support MSMEs. So, all state companies required to partner with MSMEs are solely to support MSMEs, not to provide financial benefits to SOEs.

Although many previous studies on MSMEs' exports were valuable, no empirical studies have ever been made, at least in Indonesia, on the importance of partnership for MSMEs to do export based on a national survey on MSEs in the manufacturing industry. So, based on the above background, how important is a partnership in supporting MSMEs to export is the only question in this study. Thus, this study aims to answer this research question. The significance of this study is that it enriches the general framework of the MSMEs' export market involvement by using macro-level data.

\section{Literature Review}

Generally, the market orientation of MSME is different from that of their larger counterpart. Most of the former group, especially MSEs, produce cheap and straightforward consumption goods that are often considered inferior goods for local poor or low-income buyers. However, there is much evidence that these tiny enterprises, at least some of them, do export, either directly or indirectly through, e.g. subcontracting or marketing arrangements with larger exporting companies. Exporting MSEs are mainly found in furniture, foods and beverages, textile and garment, footwear, and handicrafts.

Many evidence from many countries shows that the export share of MSMEs is relatively small. Still, most of these MSME exporters, especially MSE exporters, export indirectly via intermediate agencies such as trading companies or export-oriented LEs. Wattanapruttipaisan (2005) study, for instance, showed the direct contribution of MSMEs to total export earnings in ASEAN was much less than $50 \%$, although it varied by country. This view is supported by a report from APEC (2002) on the development of MSMEs in the Asia Pacific (AP) region. According to this report, on average, MSMEs contributed less than $30 \%$ of direct exports, so they were underrepresented in the international economy relative to their role in the domestic economy. The report took the indirect exports of MSMEs into account; the contribution to total exports would be above that proportion. It was further explained that, especially in the manufacturing industry, many MSMEs in some member countries made up a significant part of the value chain in a production process, and therefore were not included indirect exports.

Based on the results from the World Bank Enterprises Surveys, in the AP region, the share of MSMEs that exported directly and where direct exports constituted at least $10 \%$ of total annual sales ranged from as little as $5.6 \%$ in Thailand to as high as $23.5 \%$ in Malaysia (Table 1). Indonesian MSMEs have a recorded share of around 13.2\%. Only in Papua New Guinea, the share of MSMEs that exported directly was higher than that of LEs. In terms of the share of total sales exported directly by the company, this ranged from an average of $2.8 \%$ for MSMEs in Thailand to $9.8 \%$ for MSMEs in Malaysia. Again, apart from Papua New Guinea, LEs exported a higher share of their total sales than MSMEs. This evidence confirms that direct export is much more complicated than indirect export for most export-oriented MSMEs, especially MSEs. 
Table 1: Exporters as a Share of Firms and Exports as a Share of Total Sales by Size in Several Economies in the AP Region (\%)

\begin{tabular}{|c|c|c|c|c|c|c|c|}
\hline \multirow[t]{2}{*}{ Economy } & \multicolumn{3}{|c|}{$\begin{array}{c}\text { Share of Firms Exported } \\
\text { Directly }\end{array}$} & \multicolumn{3}{|c|}{$\begin{array}{l}\text { Share of Total Sales } \\
\text { Exported Directly }\end{array}$} & \multirow[t]{2}{*}{ Year } \\
\hline & MSE & ME & LE & MSE & ME & LE & \\
\hline Chile & 0.8 & 3.8 & 22.5 & 0.2 & 1.5 & 5.7 & 2010 \\
\hline China & 4.6 & 12.5 & 29.4 & 3.3 & 5.7 & 13.9 & 2012 \\
\hline Indonesia & 5.3 & 7.9 & 25.2 & 2.9 & 5.0 & 11.7 & 2015 \\
\hline Malaysia & 4.3 & 19.2 & 69.0 & 2.2 & 7.6 & 30.3 & 2015 \\
\hline Mexico & 0.7 & 9.1 & 15.9 & 0.1 & 2.1 & 5.6 & 2010 \\
\hline Papua New Guinea & 11.5 & 4.9 & 0.0 & 1.2 & 2.1 & 0.2 & 2015 \\
\hline Peru & 4.6 & 16.3 & 26.9 & 2.3 & 7.3 & 12.0 & 2017 \\
\hline Philippines & 3.9 & 9.0 & 23.6 & 1.8 & 6.1 & 16.6 & 2015 \\
\hline Russia & 4.6 & 5.5 & 6.6 & 2.4 & 3.1 & 1.6 & 2012 \\
\hline Thailand & 2.2 & 3.4 & 28.1 & 0.8 & 2.0 & 18.9 & 2016 \\
\hline Viet Nam & 4.0 & 11.5 & 36.1 & 2.2 & 6.6 & 21.6 & 2015 \\
\hline
\end{tabular}

Note: the share of firms that exported directly included only companies with direct exports of at least 10 per cent of total annual sales.

Source: The World Bank Enterprise Surveys (www.enterprisesurveys.org.).

The literature on MSMEs' export has grown in the past few decades, concluding that MSMEs have export potential. Still, they faced many constraints which limited them to participate in export activities fully. The literature includes Julien \& Ramangalahy (2003), Leonidou (2004), Jones \& Coviello (2005), Belso-Martínez (2006), Soulaimane (2011), Leonidou et al. (2007), Arteaga-Ortiz \& Fernández-Ortiz (2010), Mpunga (2016), Alam (2017), Breckova (2018), Ribau et al. (2018), Dabić et al. (2020), and Chandra et al. (2020). Many of these studies conclude that the weakness of MSMEs, especially MSEs, in export compared to LEs is closely related to their size. For instance, Julien \& Ramangalahy (2003) research indicates that the limited ability to acquire information and knowledge about foreign markets and manage foreign activities is mainly responsible for MSMEs' relatively low exporting commitment and poor performance. Belso-Martínez (2006) found that because of these limitations, industrial districts or clusters have been increasingly recognized as an organizational model enabling MSMEs to become exporters and to compete internationally. Based on their findings, as Soulaimane (2011), Ribau et al. (2018), and Dabić et al. (2020) stated that their small size and limited resources might constrict MSMEs' involvement in international business activities. Owing to their lack of resources, MSMEs are averse to the risk of failure in international market operations. Chandra et al. (2020) reviewed the literature on internationalization barriers of MSMEs from developing countries. The purposes of their study are: (1) to explicitly point out specific factors influencing the growth and internationalization of MSMEs from developing countries and (2) to identify the research gaps to provide lucid and concise directions for future research in this area. They found that many questions remain unanswered regarding the internationalization of MSMEs from developing countries regarding the factors determining their growth and internationalization.

According to Suwandi (2012), based on his field research and his long experience fostering MSMEs' export in Indonesia. There were three main motivations for MSMEs to export: first, 100 per cent business motivation (expanding markets and increasing turnover); Business and social motivation (promoting local community's businesses); Trial and error' (trying abroad while still selling on the domestic market). 
Revindo et al. (2019) have investigated the main factors influencing Indonesian MSMEs' decisions and ability to engage in direct export activities based on a survey of 271 exporting MSMEs and 226 non-exporting MSMEs in seven provinces in Java, Madura, and Bali. They found that compared to large enterprises (LEs), MSMEs are less able to take advantage of the growing export opportunities as a positive impact of the increasingly free world trade. They argue that their relatively poor export performance persists, despite various policy measures launched by the Indonesian government. They argue that their relatively poor export performance persists, despite various policy measures established by the Indonesian government. Such assistance includes public access to credit, technical and managerial training, and export-specific assistance (including trade promotion, business matching, and export procedures training).

Most export-oriented MSMEs in Indonesia were found in clusters. Many MSMEs inside clusters were previously only served local or national markets, but they also sold their products directly or indirectly abroad. Some clusters are more developed than others in export activities, mainly because they have well-developed long-term subcontracting arrangements. Domestic exporting big companies or trade contracts with domestic trading companies/agents or distributors in importing countries (Perry \& Tambunan, 2009; Tambunan, 2010; 2013, 2015a,b).

Another essential characteristic of Indonesian MSMEs involved in export activities is that most of them do not export by themselves or not directly, but indirectly through various intermediaries, including collectors, or partner with exporting or international/regional trading companies or cooperatives (Figure 2). Indirect exports through, for instance, a trading company can take various forms, including subcontracting in which MSMEs only make a particular part of a good (for example, 75\%). In contrast, the trading company completes it into a finished good, or MSMEs produce $100 \%$ of a good ordered by the trading company. At the same time, the latter only needs to wrap it up and give a brand. In most cases, in this type of partnership, the trading company also determines almost everything that ranges from the shape and volume of goods, colour, quality standard, and kind of raw materials to be used.

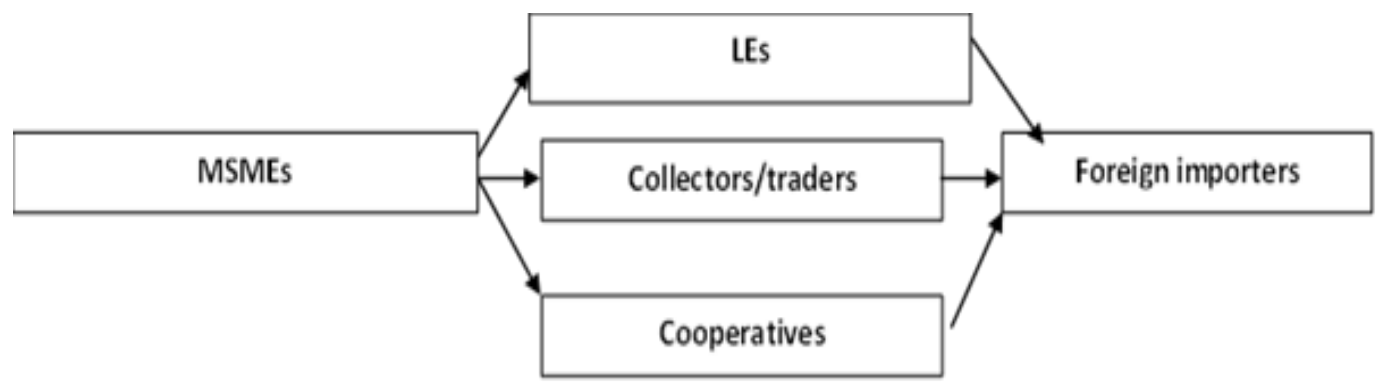

Figure 2: MSME Indirect Export Model in Indonesia

For example, findings from a survey of MSMEs in several industry groups in seven big cities in Java conducted by Urata (2000) showed that not all respondents exported directly but through various types of intermediaries. Especially beginners in export who did not have any experience were very dependent on trading companies or export-oriented large-sized companies.

In Indonesia, this way of exporting is usually done by, e.g. furniture manufacturers mainly exported to Europe and sponge rubber footwear (sandals) manufacturers who sold to several Arab countries and the Netherlands. Before the Asian financial crisis in 1997-1998, Indonesian MSMEs in the furniture and apparel industries were very active in export. According to Berry \& Levy (1999), subcontracting linkages with LEs were very common in MSMEs that export rattan furniture and apparel. They stated that the export growth of MSMEs in these 
industries reflected the increasing importance of subcontracting with LEs or other commercial intermediaries. Berry et al. (2001) concluded that linking production with trading companies with a subcontracting system is an excellent way to help MSMEs export in the short term. Because with this system, MSMEs do not have to bother managing all administration related to exports. While on the other hand, through collaboration with LEs, MSMEs can learn a lot about how to export and make export goods that meet international standards and have high competitiveness in the global market.

For many exporting MSMEs, there are reasons not to ship directly. It could be that the number of goods they produced was not sufficient for direct export because their production capacity was limited. So that export costs, especially transportation, were costly; or lack of experience to export directly or the local producers do not have buyers abroad. So it is much cheaper and more profitable for them to export by partnering with, e.g. international trading companies with many experiences and already market networks abroad.

For MSMEs that export directly without intermediaries, it is not always in the sense that they send their products to foreign markets. Many sold their goods to foreign tourists, which in the International Monetary Fund's (IMF) version of the balance of payments is also defined as a category of exports. MSMEs that carried out export activities like this are often referred to as market-oriented MSMEs for foreign buyers. For example, Cole (1998) and Sandee et al. (2000) found most export-oriented MSMEs in clusters across several industries. (i.e. furniture and apparel in Jakarta, apparel in Bali province, and wood furniture in Jepara in Central Java province) operated on commodity-driven buyers by visiting foreign tourists. So, driven by these foreign tourists, MSMEs in these furniture industry clusters in Jepara and the Bali cluster's apparel industry cluster have relatively easily penetrated global markets through trade networks. The research also clearly showed the vital role of foreign tourists in connecting the producers in these clusters with foreign markets, modernizing production methods, and improving the quality of goods produced in these clusters.

Table 2 presents the main findings of other research papers on determinant factors or main constraints of MSMEs' exports. Some papers provided comprehensive literature reviews on the issue. Many articles were based on field surveys on exporting MSMEs in many parts of the world.

\section{Table 2: Main Findings from Selected Important Research Papers on Determinants of MSMEs' ability to do Direct Export}

\begin{tabular}{|c|c|}
\hline Research paper & Main findings \\
\hline $\begin{array}{l}\text { Madushanka \& Sachitra } \\
\text { (2021) }\end{array}$ & $\begin{array}{l}\text { Positive domestic supply factors: financial capability, management capability, } \\
\text { government policies. }\end{array}$ \\
\hline Kharel \& Dahal (2020) & $\begin{array}{l}\text { Negative domestic supply factors: an inadequately trained/skilled } \\
\text { workforce; onerous collateral requirements and high-interest rates when } \\
\text { accessing credit; a poorly funded concessional export credit scheme, with } \\
\text { a short term length; procedural difficulty in accessing a cash export subsidy } \\
\text { program; high tariffs on raw materials and intermediate goods coupled with } \\
\text { an ineffective duty drawback system; the lack of an efficient arrangement } \\
\text { for consolidating less-than-container-load cargoes; poor dissemination of } \\
\text { information about existing incentives and facilities; inadequate provision } \\
\text { of trade and market intelligence; restrictions on online payment solutions; } \\
\text { a weak capacity of the public administration to coordinate and implement } \\
\text { trade and industrial policies, lack of policy supports in the form of fiscal } \\
\text { incentives and policy uncertainty. }\end{array}$ \\
\hline
\end{tabular}




\begin{tabular}{|c|c|}
\hline Research paper & Main findings \\
\hline Revindo et al. (2019) & $\begin{array}{l}\text { Positive domestic supply factors: having network relationships with formal } \\
\text { and informal institutions, firm age, size (number of employees), the owners } \\
\text { have been overseas or have experience working for a multinational company } \\
\text { or an exporting large-sized firm, produce merchandise that comprises a large } \\
\text { share of Indonesia's national exports (foreign buyer), receive assistances } \\
\text { from central government agencies or non-governmental sources (including } \\
\text { promotion, business management, finance, and production). } \\
\text { Negative domestic supply factors: human resource barriers. } \\
\text { Negative foreign demand factors: perceive difficulties in overcoming any } \\
\text { tariff and non-tariff barriers, distribution, logistic, business environment, } \\
\text { procedural and competitor barriers in host countries }\end{array}$ \\
\hline $\begin{array}{l}\text { Tham \& Tambunan } \\
(2019)\end{array}$ & $\begin{array}{l}\text { Important domestic supply factors: compliance with international quality } \\
\text { standards, networks, training, market information. }\end{array}$ \\
\hline Haddoud et al. (2018) & $\begin{array}{l}\text { Positive domestic supply factors: possession of resources and capabilities } \\
\text { such as innovative and marketing factors to be complemented by firms } \\
\text { owners who are export-oriented and have the relevant attributes in terms } \\
\text { of export knowledge and experience. }\end{array}$ \\
\hline Alam (2017) & $\begin{array}{l}\text { Important domestic supply factors: foreign ownership, international } \\
\text { certification, foreign technology, establishment in export processing zones. }\end{array}$ \\
\hline Mpunga (2016) & $\begin{array}{l}\text { Important domestic supply factors: adequate and stable financial capital, } \\
\text { knowledge of the foreign language, production technology, information and } \\
\text { communication technology (ICT), information search competencies. } \\
\text { Important foreign demand factors: standard products, restrictive entrance } \\
\text { procedures into the importing country, export market characteristics (e.g. } \\
\text { complicated business laws/regulations, customers' indifference with foreign } \\
\text { goods, price uncertainty in the export markets, product competition in the } \\
\text { export market, and complicated travel accreditation). }\end{array}$ \\
\hline Revindo \& Gan (2017) & $\begin{array}{l}\text { Positive domestic supply factors: the aspiration to find alternative markets, } \\
\text { networking and information dispersion } \\
\text { Positive foreign demand factors: the presence of foreign buyers, the } \\
\text { confidence in the products. }\end{array}$ \\
\hline Harchegani, et al. (2015) & $\begin{array}{l}\text { Positive domestic supply factors: environmental factors (e.g. stability in } \\
\text { political, economic and legal environment, database to access taste of export } \\
\text { markets, and attractiveness of export markets), managers' commitment to } \\
\text { export (e.g. a separate export unit, regular visit of export markets, and using } \\
\text { export market research), managers' export marketing strategy (e.g. product } \\
\text { adaptation strategy, pricing adaptation strategy, product innovation strategy, } \\
\text { foreign advertisement, new products), export incentives (e.g. export } \\
\text { motives, export problems, and competition), objective characteristics of } \\
\text { the firm (e.g. size, export experience, expert human resource and sufficient } \\
\text { financial). }\end{array}$ \\
\hline Nyatwongi (2015) & $\begin{array}{l}\text { Important domestic supply factors: policy and legal framework, market } \\
\text { information, tax, technology, finances and management skill. }\end{array}$ \\
\hline Fakih \& Ghazalian (2014) & $\begin{array}{l}\text { Positive domestic supply factors: private foreign ownership, information } \\
\text { and communication technology, firm size. } \\
\text { Negative domestic supply factors: government ownership, domestic market } \\
\text { size. }\end{array}$ \\
\hline $\begin{array}{l}\text { Hoekman \& Shepherd } \\
\text { (2013) }\end{array}$ & Positive domestic supply factors: trade facilitation, firm size, firm ownership \\
\hline
\end{tabular}




\begin{tabular}{|c|c|}
\hline Research paper & Main findings \\
\hline Shepherd \& Duve (2013) & $\begin{array}{l}\text { Positive domestic supply factors: availability of funds, management } \\
\text { attitudes, knowledge of the market risk perception, international networks, } \\
\text { intensity of competition. }\end{array}$ \\
\hline $\begin{array}{l}\text { Amornkitvikai et al. } \\
\text { (2012) }\end{array}$ & $\begin{array}{l}\text { Positive domestic supply factors: government assistance, foreign ownership, } \\
\text { municipal location, R\&D, skilled labor, firm size and age, labor productivity. }\end{array}$ \\
\hline Cardoza et al. (2012) & $\begin{array}{l}\text { Negative domestic supply factors: limited access to finance, domestic } \\
\text { inefficiencies in logistics and distribution, high international transport costs, } \\
\text { payment collection costs, adverse regulatory frameworks, }\end{array}$ \\
\hline Petrit et al. (2012) & $\begin{array}{l}\text { Positive domestic supply factors: firm size, ownership, sector of activity, } \\
\text { the availability of external finance, affiliation with business organizations, } \\
\text { education of the workforce and, to a lesser extent, technology-related } \\
\text { factors. }\end{array}$ \\
\hline Wignaraja (2012) & $\begin{array}{l}\text { Positive domestic supply factors: firm size, foreign ownership, worker with } \\
\text { high skills, obtaining international-agreed certificates (such as ISO), having } \\
\text { access to foreign technology, having access to bank's credit. }\end{array}$ \\
\hline $\begin{array}{l}\text { Ottaviano \& Martincus } \\
\text { (2011) }\end{array}$ & $\begin{array}{l}\text { Positive domestic supply factors: technology, training (human resource } \\
\text { development), investment in product improvement. }\end{array}$ \\
\hline Dios (2009) & $\begin{array}{l}\text { Positive domestic supply factors: skill, technology and access to finance, ICT- } \\
\text { based trade facilitation measures. }\end{array}$ \\
\hline Li and Wilson's (2009) & $\begin{array}{l}\text { Positive domestic supply factors: trade facilitation, access to finance, skilled } \\
\text { workers, technology, and market information. }\end{array}$ \\
\hline Hessels \& Terjesen (2007) & $\begin{array}{l}\text { Positive domestic supply factors: adopting legitimate business or industry } \\
\text { practices, access to key resources (e.g. technology, capital, market } \\
\text { information, raw materials, international marketing knowledge). }\end{array}$ \\
\hline Valodia \& Velia (2004) & $\begin{array}{l}\text { Negative domestic supply factors: cost of imported inputs/raw materials, } \\
\text { poor business linkages, exchange rate movements, lack of production } \\
\text { capacity, disability to produce high or international standard quality goods. } \\
\text { licensing/paten rights, firm size, lack of knowledge of international markets. } \\
\text { Negative foreign demand factors: high tariffs, import licensing and other } \\
\text { non-tariff barriers, anti-dumping actions, unreliable firms as overseas } \\
\text { importers, niche markets where demand was not price sensitive, illegal } \\
\text { custom control procedure. }\end{array}$ \\
\hline Sandee \& Ibrahim (2002) & $\begin{array}{l}\text { Negative domestic supply factors: high transaction costs, high wage of } \\
\text { workers, lack of access to formal credit. } \\
\text { Negative foreign demand factor: increasing competitions from other } \\
\text { exporting countries. }\end{array}$ \\
\hline Hine \& Kelly (1997) & $\begin{array}{l}\text { Positive domestic supply factors (inside firms): attitudes, values, perceptions } \\
\text { of risk, continuous learning, managerial and marketing skills, availability } \\
\text { of resources (including financial resources), adjustment of organizational } \\
\text { structure, and the availability and effective use of information. }\end{array}$ \\
\hline
\end{tabular}

From the literature review, it was evident that many direct and indirect factors simultaneously affect MSMEs' export performance or export capability. But there is still very little attention to the role of partnerships. Theoretically, factors affecting MSMEs' export can be grouped into demand and supply factors that originate from the demand-side and supply-side of the market, respectively (Figure 3). It can distinguish the demand factors further into policy factors such as import tax and trade regulations and non-policy factors such as buyer's taste, 
income, exchange rate, and market competition in the importing countries. Similarly, it can distinguish supply factors between policy and non-policy factors previously mentioned in the literature review. Non-policy factors are internal factors of the company, supporting organisations such as LEs, banks, universities, government departments and many others, and other supply factors such as infrastructure and logistics, trade regime, availability of natural resources, and many others.

It is generally expected that MSMEs having partnerships with those supporting organisations are more able or have more capacity to export than those who are not, ceteris paribus. Through partnerships, MSMEs have access to information on foreign markets, technologies, capital, knowledge on international marketing and many other resources needed for doing exports.

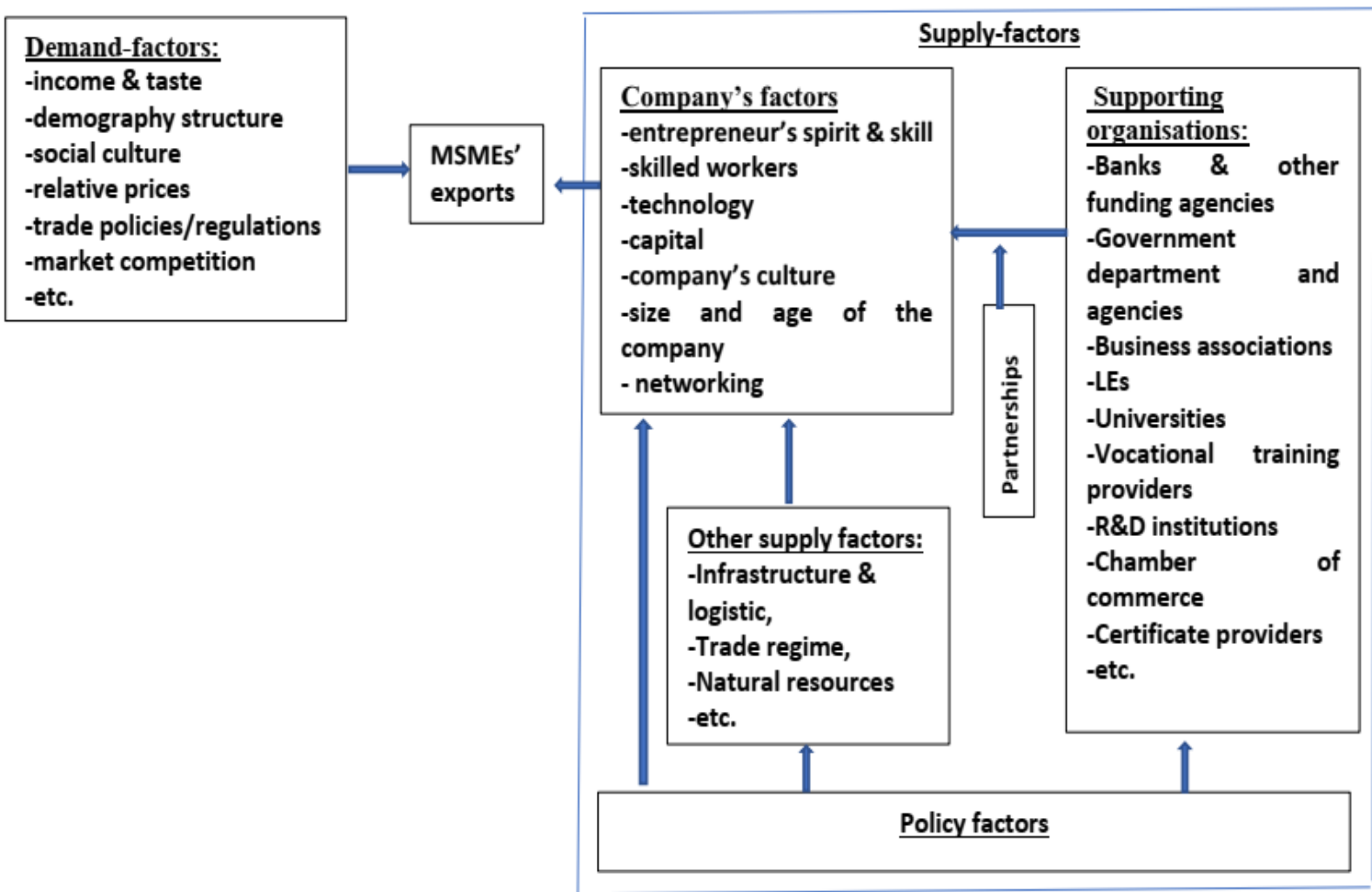

Figure 3: Demand and Supply Determinants of MSMEs' Exports

\section{Data and Method}

It is a descriptive study. It used secondary data from the results of the 2019 Survey of MSEs in the manufacturing sector (called from now on as micro and small industries or MSIs) with a workforce of less than 20 conducted by the Indonesian Central Statistics Agency (BPS). The data includes the number of companies, workforce, worker remuneration, expenses, income, capital, business difficulties, business services and guidance, and marketing distribution. The survey also provides information on the number of MSEs which have partnerships with LEs. The data is presented according to The Indonesian Standard Classification Code for Business Fields (KBLI) is two-digit and by province. Based on KBLI, the manufacturing sector consists of 23 groups, including the food industry, textile and garment industry, leather industry, etc. In this survey, microenterprises (MIEs) are defined as enterprises with 1 to 4 workers and small enterprises (SEs) with 5 to 19 workers. 


\section{Results and Discussion}

\section{Export Performance}

This 2019 data indicates that although it varies by industry group, marketing of MSIs' products was dominated by local marketing in their own districts/cities, which reached 89.15\%. Meanwhile, marketing outside their districts/cities, either still in their province or in other provinces, was still not developed. These two marketing allocations were respectively $7.57 \%$ and $2.79 \%$. Meanwhile, foreign markets that MSIs could reach were still relatively small. MSIs' exports were only $0.50 \%$ of their total products.

Regarding the number of MSIs that export, they were not so much, only 29,071 units or around $0.66 \%$ of the total $4,380,176 \mathrm{MSIs}$; although the ratio varies by industry group. Unfortunately, the 2019 data does not discuss indicators of export performance of MSIs besides the number of MSEs that participate in exports and the percentage of total production for export.

As can be seen in Figure 4, besides in the other processing industry group (KBLI 33), the highest percentage of MSIs that was recorded export in the non-machined metal goods and their equipment industry group (KBLI 25) that reached almost 5.9\% of the total 3,743 MSIs in that industry. The non-metal mineral industry group (KBLI 23) was the second rank, with almost $2.55 \%$ of $14,324 \mathrm{MSI}$. This variety could be caused by many factors ranging from production capacity. The types of goods further determine the level of complexity in producing and marketing them abroad, such as the types and availability of required raw materials, the level of competition and opportunities in the export market, differences between industry groups in the level of development of the export-oriented MSIs clusters, or location of the company far from ports. Further, as can be seen, no MSIs were involved in export activities for various reasons in some industry groups. It can be that their exports were not recorded because they did export not for the whole year. Only occasionally and in a small quantity if there happened to be an export-oriented trader ordered it, or maybe local industry-specific regulations were not. So business-friendly that made it difficult for the MSIs to export, or the owners of MSIs preferred only local or domestic markets because demand was always high.

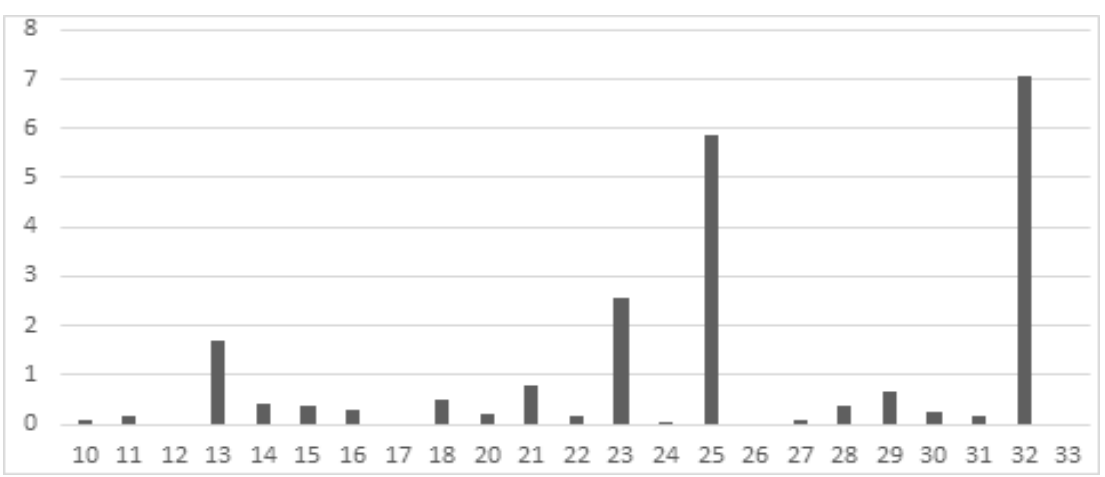

Group of industry

Figure 4: Percentage of MSIs involved in Export by Group of Industry, 2019

Note: 10: food, 11: beverages, 12: tobacco processing, 13: textiles, 14: apparel, 15: leather, leather goods and footwear, 16: wood, wood products and cork (excluding furniture), woven articles from rattan, bamboo and the like, 17: paper and paper articles, 18: printing and reproduction of recorded media, 20: chemicals and articles of chemical substances, 21: pharmaceuticals, chemical medicinal products and traditional medicine, 22: rubber, articles of rubber and plastics, 23: non-metal minerals, 24: base metals, 25: non-machined metal goods and their equipment, 26: computers, electronic and optical goods, 27: electrical equipment, 28 : YTDL machinery and equipment (excluding others), 29: motor vehicles, trailers and semi-trailers, 30: other means of transportation, 31: furniture; 32: other processing; 33: repair and installation of machinery and equipment

Source: BPS (2020) 
However, not all of them have sold all their products to international markets. As can be seen in Table 3, the proportion exported varies. The number of MSIs that exported more than $80 \%$ was only about $44 \%$ of the total MSIs involved in exports. Although no further information is available, many reasons can be guessed why many MSIs involved in export did not sell all of their products to international markets. It could be because they were short of funds to finance export costs (i.e. selling abroad is undoubtedly more expensive than selling locally) or that selling abroad was not their primary market destination. For instance, the main target for most small furniture producers in rural Java has always been the local or domestic markets because Indonesia, with a massive population of 269 million people, makes the domestic market very attractive to them. Some of them have also been sold abroad because there was an opportunity for export at that time. Such options could arise from orders made by small or medium-sized traders or collectors from surrounding cities who visited specific MSI clusters in rural areas. It could be that trading houses ordered a certain amount. Still, not much to meet the demands came from several individual buyers from outside (so it was not a routine and large order from a company or organization). Even a foreign market opportunity could arise from a foreign tourist who owned or managed a small hotel in their home country, visiting a furniture industry cluster in Indonesia. Then made a business contract with a manufacturer in the group to supply a certain number of chairs, tables, beds or cabinets. The emergence of opportunities like this was experienced by many furniture producers in Jepara (Central Java Province), which is still the most famous centre for the furniture industry until now in Indonesia.

Table 3: Number of MSIs' involved in Export by Percentage Export and Group of Industry, 2019

\begin{tabular}{|c|c|c|c|c|}
\hline \multirow{2}{*}{ Industry } & \multicolumn{4}{|c|}{ Percentage } \\
\hline & $1-24$ & $25-49$ & $50-79$ & $\geq 80$ \\
\hline 10 & 1395 & 12 & 92 & 149 \\
\hline 11 & - & - & - & 153 \\
\hline 12 & - & - & - & - \\
\hline 13 & 817 & 863 & 332 & 3023 \\
\hline 14 & 1024 & 696 & 181 & 759 \\
\hline 15 & 96 & 7 & 114 & - \\
\hline 16 & 401 & 44 & 381 & 1201 \\
\hline 17 & - & - & - & - \\
\hline 18 & 154 & 4 & - & - \\
\hline 20 & 11 & - & 8 & 57 \\
\hline 21 & 15 & 4 & - & - \\
\hline 22 & 25 & - & - & - \\
\hline 23 & 220 & 2 & 20 & 123 \\
\hline 24 & 17 & - & - & - \\
\hline 25 & 110 & 14 & 20 & 78 \\
\hline 26 & - & - & - & - \\
\hline 27 & - & 82 & - & 36 \\
\hline 28 & 5 & - & - & - \\
\hline 29 & 12 & 6 & - & - \\
\hline 30 & - & - & - & 17 \\
\hline 31 & 37 & 36 & 98 & 52 \\
\hline 32 & 479 & 53 & 8385 & 7153 \\
\hline 33 & - & - & - & - \\
\hline
\end{tabular}




\section{The Importance of Partnership}

In Indonesia, one of the government's efforts to support the development of MSMEs, especially MSEs, is by issuing some regulations and providing incentives to promote partnership between MSIs and larger enterprises and other agencies. The collaboration in question is mutually beneficial business cooperation for both parties involved. However, data 2019 indicates that the number of MSIs that did partnership was relatively small, only $8.28 \%$ of the total 4.38 million MSIs. Although, as shown in Table 4, the ratio varied by a group of industries. BPS defines partnership as a cooperative relationship with other businesses/companies (including SOCs) mutually benefiting, strengthening, and supporting. Unfortunately, the 2019 data does not discuss the nature of partnerships besides explaining the services provided by partners of MSEs.

Table 4: Number and Percentage of MSEs involved in Export by Group of Industry and Partnership, 2019

\begin{tabular}{|c|c|c|c|c|c|}
\hline \multirow{2}{*}{ Industry } & \multirow{2}{*}{$\begin{array}{c}\text { Number of } \\
\text { MSEs }\end{array}$} & \multicolumn{2}{|c|}{ Exporter } & \multicolumn{2}{|c|}{ Partnership } \\
\hline & & Number & $\%$ & Number & $\%$ \\
\hline 10 & 1587019 & 1648 & 0.10 & 121200 & 7.64 \\
\hline 11 & 98901 & 153 & 0.16 & 6583 & 6.66 \\
\hline 13 & 296154 & 5035 & 1.7 & 34284 & 11.58 \\
\hline 14 & 613668 & 2660 & 0.43 & 64298 & 10.48 \\
\hline 15 & 57332 & 217 & 0.38 & 9633 & 16.8 \\
\hline 16 & 658426 & 2027 & .031 & 33865 & 5.14 \\
\hline 18 & 31598 & 158 & 0.5 & 4301 & 13.61 \\
\hline 20 & 34590 & 76 & 0.22 & 1283 & 3.71 \\
\hline 21 & 14597 & 19 & 0.78 & 1154 & 47.18 \\
\hline 22 & 14324 & 25 & 0.17 & 4733 & 32.43 \\
\hline 23 & 240141 & 365 & 2.55 & 11309 & 78.95 \\
\hline 24 & 3743 & 17 & 0.01 & 81 & 0.03 \\
\hline 25 & 120732 & 220 & 5.88 & 9685 & 8.02 \\
\hline 27 & 1331 & 118 & 0.1 & 327 & 24.57 \\
\hline 28 & 2631 & 5 & 0.38 & 291 & 11.06 \\
\hline 29 & 2466 & 18 & 0.68 & 111 & 4.54 \\
\hline 30 & 7202 & 17 & 0.24 & 587 & 8.15 \\
\hline 31 & 144775 & 223 & 0.15 & 10816 & 7.47 \\
\hline 32 & 227408 & 16070 & 7.07 & 24603 & 10.82 \\
\hline
\end{tabular}

Source: BPS (2020)

The most popular partnership was a product marketing partnership which recorded at $37.59 \%$. The second was a partnership for the procurement of raw materials with $37.56 \%$, and the third was a partnership related to capital goods at $16.72 \%$. Private larger companies were the biggest party in collaboration with MSIs, which was $36.8 \%$. The involvement of government, i.e. state-owned companies both at the central level (BUMN) and local/regional level (BUMD), and local government agencies/departments such as the regional office of cooperative and SMEs was minimal, only $3.3 \%$, and $5.65 \%$, respectively. It is undoubtedly a challenge for the government to partner with MSIs to contribute directly to the solution of the problems and difficulties faced by these manufacturing enterprises. Other institutions/agencies that did partnerships with MSIs were banking and non-government organizations such as business associations, vocational training agencies, and chamber of commerce and industry NGOs (Figure 5). 


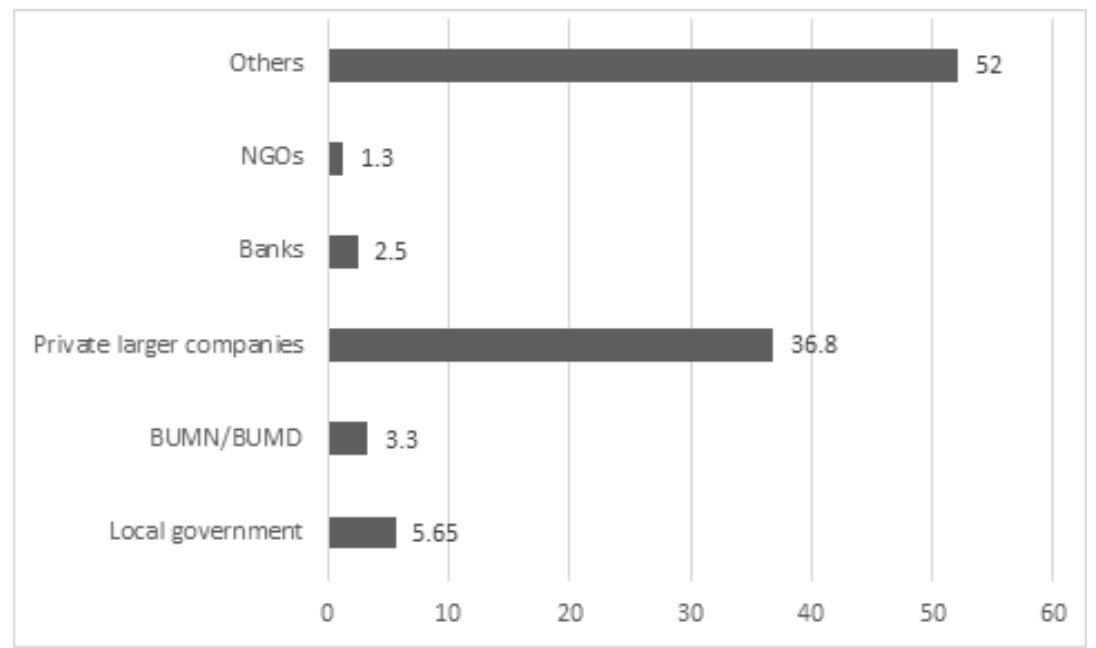

Figure 6: Percentage of Types of Partnership Conducted by MSIs, 2019

Source: BPS (2020)

Unfortunately, the 2019 data from the MSI survey in the manufacturing industry throughout Indonesia does not provide further information on how involved many of those having partnerships in exports, especially those that did marketing partnerships. However, as this survey also shows that the most severe obstacle experienced by most MSIs was marketing, it can assume that the marketing partnership was beneficial for export-oriented MSIs. The scatter plot in Figure 7 may support this assumption. Other previous studies from such as also support this assumption.

Revindo et al. (2019), Petrit et al. (2012), Shepherd \& Duve (2013), and Wood et al. (2009) emphasize that network relationships are among essential determinant factors of MSMEs exports. But, to prove it statistically, more data is needed, especially regarding MSMEs that carry out marketing partnerships and export.

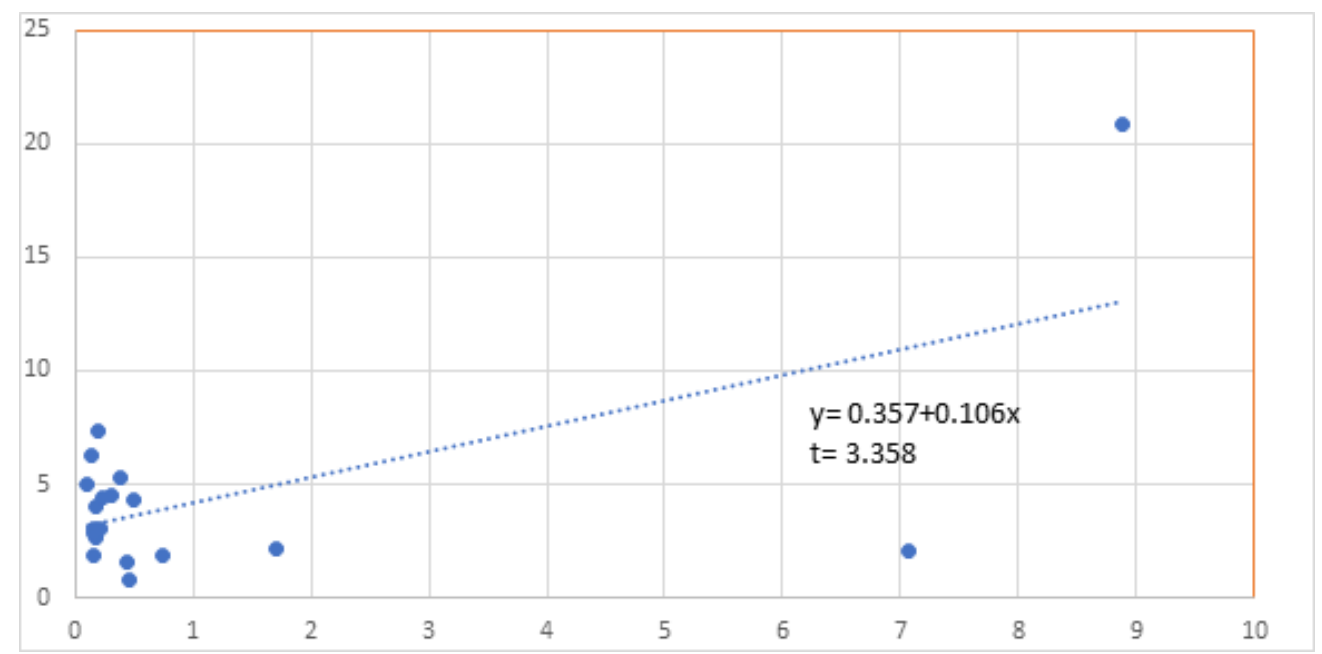

Figure 7: Scatter Plot of Percentage of MSIs doing Export and Percentage of MSIs doing Marketing Partnership

Source: BPS (2020)

One successful partnership between MSEs and LEs that creates export opportunities to the former is an agricultural cooperative of small banana farmers, named the Koperasi Tani Hijau Makmur in Tanggamus District, the Province of Lampung in South Sumatera, Indonesia. 
It partnered with a large company called PT Great Giant Pineapple (GGP) to cultivate more than 400 hectares of banana tree land. Through this partnership, the cooperative, which has 820 banana farmers, managed to export 64 tons of bananas or 14,266 boxes per month in 2020. Its export destinations include China, Malaysia, Singapore, and the Middle East. Those farmers by themselves whose land ownership is narrow cannot possibly build a corporate farm that can produce products in large quantities that meet international quality standards and in a continuous process that can meet foreign market demands (Ubaidillah, 2021).

\section{Conclusion}

As stated earlier, there has been quite a lot of research on the ability of MSEs in developing countries to export, especially directly. Factors affecting the ability of MSEs to export have been found or identified. However, it isn't easy to find research analysing the role of partnerships in supporting the export of MSEs. This study aims to fill this gap in the literature with the Indonesian case. The 2019 data on MSIs in the manufacturing industry used in this study shows that marketing partnership is the most widely practised by MSIs. But, this study is not able to prove that relationship statistically. Unfortunately, the analysis in this study with the 2019 data only gives a strong impression that marketing partnerships play an essential role in encouraging the export growth of MSMEs.

\section{Research Limitations}

This study has two main limitations. First, there is no further information from this study's 2019 national survey data regarding how many of the MSIs that carried out marketing partnerships also did export. In other words, whether all MSIs that have marketing partnerships also exported their goods is a question that this study cannot answer. And so, this study is not able to prove statistically the assumed positive relationship between MSMEs having marketing partnership and their ability to export. Although it is not easy and it will take a lot of time to identify MSMEs that export and do marketing partnerships with, for example, LEs or partners abroad, primary data is needed to answer this research's questions.

The second limitation is the nature of the data used is static, that is, only one period. At the same time, it must study the export capability of a company over a long period because the international market is very dynamic. The demand for an exporter's products may change (e.g. decrease) due to the emergence of new competitors, changes in buyer tastes, or technological changes. Therefore, a survey of MSMEs that export and at the same time also have marketing partnerships should be carried out over two different periods with a distance of, for example, a year to see if the marketing partnership does increase their exports.

\section{References}

ADB. (2015). Asia SME Finance Monitor 2014. https://www.adb.org/sites/default/files/publication/173205/asia-sme-finance-monitor2014.pdf

Alam, M. S. (2017). Participation of Emerging Markets in Global Value Chains (GVCs) and Factors Hindering the Operations of Small and Medium Enterprises (SMEs). International Journal of Small and Medium Enterprises and Business Sustainability, 2(3), 1-21.

Amornkitvikai, Y., Harvie, C., \& Charoenrat, T. (2012). Factors affecting the export participation and performance of Thai manufacturing small and medium sized enterprises (SMEs). 57th International Council for Small Business.

APEC. (2002). Profile of SMEs and SME Issues in APEC 1990 - 2000. https://www.apec.org/ 
docs/default-source/publications/2003/12/profile-of-small-and-medium-enterprisessmes-and-sme-issues-in-apec-19902000-published-in-2003/03_sme_profile90to00.pdf

Arteaga-Ortiz, J., \& Fernández-Ortiz, R. (2010). Why don't we use the same export barrier measurement scale? An empirical analysis in small and medium-sized enterprises. Journal of Small Business Management, 48(3). https://doi.org/10.1111/j.1540627X.2010.00300.x

ASEAN. (2015a). ASEAN Strategic Action Plan for SME Development 2016-2025. https://asean.org/wp-content/uploads/2015/12/SAP-SMED-Final.pdf

ASEAN. (2015b). External Relations. Jakarta: ASEAN Secretariat.

Belso-Martínez, J. A. (2006). Do industrial districts influence export performance and export intensity? Evidence for Spanish SMEs' internationalization process. European Planning Studies, 14(6), 791-810. https://doi.org/10.1080/09654310500496115

Berry, A., \& Levy, B. (1999). Technical, Marketing and Financial Support for Indonesia's Small and Medium Industrial Exporters. In Fulfilling the Export Potential of Small and Medium Firms. https://doi.org/10.1007/978-1-4615-5169-0_2

Berry, A., Rodriguez, E., \& Sandee, H. (2001). Small and medium enterprise dynamics in Indonesia. Bulletin of Indonesian Economic Studies, 37(3), 363-384. https://doi. org/10.1080/00074910152669181

BPS. (2020). Profil Industri Mikro dan Kecil 2019. Badan Pusat Statistik. https://www.bps. go.id/publication/download.html?nrbvfeve=ZGlyZmRmMTU4ODI1YWZiODBhMTEzYjZh\&xzmn=aHR0cHM6Ly93d3cuYnBzLmdvLmlkL3B1YmxpY2F0aW9uLzIwMjAvMTEvMTYvZGIyZmRmMTU4ODI1YWZiODBhMTEzYjZhL3Byb2ZpbC1pbmR1c3RyaS1taWtyby1kYW4ta2VjaWwtMjAxOS5odG1s\&twoadfnoarf

Breckova, P. (2018). Export patterns of small and medium sized enterprises. European Research Studies Journal, 21(1). https://doi.org/10.35808/ersj/928

Cardoza, G., Fornes, G., \& Xu, N. (2012). Institutional Determinants of Chinese SMEs' Internationalization: The Case of Jiangsu Province (No. 04-12). http://www.bris.ac.uk/media-library/sites/spais/migrated/documents/cardoza-fornes-xu-04-12.pdf

Chandra, A., Paul, J., \& Chavan, M. (2020). Internationalization barriers of SMEs from developing countries: a review and research agenda. In International Journal of Entrepreneurial Behaviour and Research (Vol. 26, Issue 6). https://doi.org/10.1108/ IJEBR-03-2020-0167

Cole, W. (1998). Bali's garment export industry. Indonesia's Technological Challenge, Research School of Pacific and Asian Studies, Australian National University, Canberra, and Institute of Southeast Asian Studies, Singapore, 255-78.

Dabić, M., Maley, J., Dana, L. P., Novak, I., Pellegrini, M. M., \& Caputo, A. (2020). Pathways of SME internationalization: a bibliometric and systematic review. Small Business Economics, 55(3). https://doi.org/10.1007/s11187-019-00181-6

Dios, L. C. de. (2009). The Impact of Information Technology (IT) in Trade Facilitation on Small and Medium Enterprises (SMES) in the Philippines. https://artnet.unescap.org/tid/artnet/mtg/tf_sme_dios.pdf 
Fakih, A., \& Ghazalian, P. L. (2014). Which firms export? An empirical analysis for the manufacturing sector in the MENA region. Journal of Economic Studies, 41(5), 672-695. https://doi.org/10.1108/JES-10-2012-0142

Haddoud, M. Y., Beynon, M. J., Jones, P., \& Newbery, R. (2018). SMEs' export propensity in North Africa: a fuzzy c-means cluster analysis. Journal of Small Business and Enterprise Development, 25(5), 769-790. https://doi.org/10.1108/JSBED-02-2017-0077

Harchegani, E. K., Solati, A., \& Fataie, P. (2015). Identifying the Factors Affecting on SMEs' Export Performance. Applied Mathematics in Engineering, Management and Technology, 3(3), 390-400.

Hessels, J., \& Terjesen, S. (2007). SME Choice of Direct and Indirect Export Modes : Resource Dependency and Institutional Theory Perspectives. Scientific Analysis of Entrepeneurship and SMEs, October.

Hine, D. C., \& Kelly, S. J. (1997). Tickets to Asia: foreign market entry and sustained competitiveness by SMEs. '10th International Conference on SMEs.' https://core.ac.uk/display/15310116

Hoekman, B., \& Shepherd, B. (2013). Who profits from trade facilitation initiatives? CEPR Discussion Paper.

Jones, M. V., \& Coviello, N. E. (2005). Internationalisation: Conceptualising an entrepreneurial process of behaviour in time. Journal of International Business Studies, 36(3), 284303. https://doi.org/10.1057/palgrave.jibs.8400138

Julien, P., \& Ramangalahy, C. (2003). Competitive Strategy and Performance of Exporting SMEs: An Empirical Investigation of the Impact of Their Export Information Search and Competencies. Entrepreneurship Theory and Practice, 27(3), 227-245. https://doi. org/10.1111/1540-8520.t01-1-00002

Kharel, P., \& Dahal, K. (2020). Small and Medium-Sized Enterprises in Nepal: Examining Constraints on Exporting (No. 1166; ADBI Working Papers). https://www.adb.org/publications/sme-nepal-examining-constraints-exporting

Leonidou, L. C. (2004). An analysis of the barriers hindering small business export development. Journal of Small Business Management, 42(3), 279-302. https://doi.org/10.1111/ j.1540-627x.2004.00112.x

Leonidou, L. C., Katsikeas, C. S., Palihawadana, D., \& Spyropoulou, S. (2007). An analytical review of the factors stimulating smaller firms to export: Implications for policy-makers. International Marketing Review, 24(6), 735-770. https://doi. org/10.1108/02651330710832685

Li, Y., \& Wilson, J. S. (2009). Time as a determinant of comparative advantage. World Bank Policy Research Working Paper, (5128).

Madushanka, H., \& Sachitra, V. (2021). Factors Influencing on Export Engagement of Small and Medium-Sized Enterprises in Sri Lanka: Resource Based View. South Asian Journal of Social Studies and Economics, 9(3), 38-49. https://doi.org/10.9734/sajsse/2021/ v9i330244

Mpunga, H. S. (2016). Examining the Factors Affecting Export Performance for Small and 
Medium Enterprises ( SMEs ) in Tanzania. Journal of Economics and Sustainable Development, 7(6), 41-51.

Nyatwongi, L. N. (2015). Factors affecting the performance of importing and exporting small and medium enterprises in Mombasa county, Kenya [University of Nairobi Collections]. http://hdl.handle.net/11295/93235

OSMEP. (2015). The White Paper on Small and Medium Enterprises of Thailand in 2015 and Trends 2016. The Office of SME Promotion.

Ottaviano, G., \& Martincus, C. V. (2011). SMEs in Argentina: Who are the exporters? Small Business Economics, 37(3), 341-361. https://doi.org/10.1007/s11187-009-9244-0

Perry, M., \& Tambunan, T. T. H. (2009). Re-visiting Indonesian cases for cluster realism. Journal of Enterprising Communities, 3(3). https://doi.org/10.1108/17506200910982028

Petrit, G., Hashi, I., \& Pugh, G. (2012). The Small and Medium Enterprise Sector and Export Performance: Empirical Evidence from South-Eastern Europe (No. 002).

Revindo, M. D., \& Gan, C. (2017). Export Stimuli, Export Stages and Internationalization Pathways: The Case of Indonesian SMEs. Economics and Finance in Indonesia, 62(3), 191-205. https://doi.org/10.7454/efi.v62i3.557

Revindo, M. D., Gan, C., \& Massie, N. W. G. (2019). Factors affecting propensity to export: The case of indonesian smes. Gadjah Mada International Journal of Business, 21(3). https://doi.org/10.22146/gamaijb.41022

Ribau, C. P., Moreira, A. C., \& Raposo, M. (2018). SME internationalization research: Mapping the state of the art. Canadian Journal of Administrative Sciences, 35(2). https://doi. org/10.1002/cjas.1419

Sandee, H., Andadari, R. K., \& Sulandjari, S. (2000). Small Firm Development during Good Times and Bad: The Jepara Furniture Industry. In Indonesia in Transition. Social Aspects of Reformasi and Crisis. Economics; AMBER.

Sandee, H., \& Ibrahim, B. (2002). Evaluation of SME Trade and Export Promotion in Indonesia. https://www.bappenas.go.id/files/1613/5229/9179/evaluation-of-sme-trade-and-export-promotion-in-indonesia__20081123085412_1027_7. pdf

Shepherd, M., \& Duve, R. (2013). Factors Affecting the Internationalisation of Manufacturing SMEs in Zimbabwe. Idrc, October.

SME Corp Malaysia. (2015). Small and Medium Enterprise (SME) Annual Report 2014/2015.

Soulaimane, L. (2011). Internationalization of SME : A reading in terms of resources and competencies. Journal of Innovation Economics \& Management, 1(7).

Suwandi. (2012). Model Jaringan Ekspor. Seminar SEADI. Jakarta.

Tambunan, T. (2010). Trade Liberalisation and SMEs in ASEAN. Nova Science Publishers.

Tambunan, T. (2013). Constraints on Indonesia's Export-oriented Micro, Small, and Medium Enterprises Secondary Data Analysis and Literature Survey. In SEADI Working Paper (2).

Tambunan, Tulus (2015a). Utilisation of Existing ASEAN-FTAs by Local Micro-, Small- and Me- 
dium-Sized Enterprises. ARTNeT Policy Brief, No. 45. May. Bangkok: ESCAP (UN).

Tambunan, Tulus T.H. (2015b). ASEAN Micro, Small and Medium Enterprises toward AEC 2015, Lambert Academic Publishing (LAP).

Tambunan, T. T. H. (2017). MSMEs and access to financing in a developing economy: The Indonesian experience. In Financial Entrepreneurship for Economic Growth in Emerging Nations. https://doi.org/10.4018/978-1-5225-2700-8.ch008

Tham, S. Y., \& Tambunan, T. (2019). Accidental and Intentional Exporters: Comparing Indonesian and Malaysian MSMEs. In Accidental and Intentional Exporters. https://doi. org/10.1355/9789814818322-002

Ubaidillah, A. (2021). Ekspor Pisang 64 Ton/Bulan, Koperasi di Lampung Dipuji Menkop UKM. DetikFinance. https://finance.detik.com/berita-ekonomi-bisnis/d-5475517/ekspor-pisang-64-tonbulan-koperasi-di-lampung-dipuji-menkop-ukm

UN-ESCAP. (2010). The Development Impact of Information Technology in Trade Facilitation. https://www.unescap.org/sites/default/files/tipub2584.pdf

Urata, S. (2000). Policy Recommendations for SME Promotion in Indonesia.

Valodia, I., \& Velia, M. (2004). Macro-Micro Linkages in Trade: How are Firms Adjusting to Trade Liberalisation, and does Trade Liberalisation. African Development and Poverty Reduction: The Macro-Micro Linkage Conference. http://www.tips.org.za/files/Micro_ evidence_of_Trade_Reform_Valodia.pdf

Wattanapruttipaisan, T. (2005). SME Development and Internationalization in the Knowledge-Based and Innovation-Driven Global Economy: Mapping the Agenda Ahead.... Seminar on "Mapping ..., May.

Wignaraja, G. (2012). Engaging Small and Medium Enterprises in Production Networks: Firm-Level Analysis of Five ASEAN Economies. SSRN Electronic Journal. https://doi. org/10.2139/ssrn.2071547

Wood, V. R., Pitta, D. A., \& Franzak, F. J. (2009). Successful strategic alliances with international partners: Key issues for small- to medium-sized enterprises. International Journal of Business Innovation and Research, 3(3), 232-251. https://doi.org/10.1504/ IJBIR.2009.024177

Yoshino, N., \& Wignaraja, G. (2015). SMEs Internationalization and Finance in Asia. IMF-JICA Conference. https://www.imf.org/external/np/seminars/eng/2015/jica2015/pdf/1-B1. pdf 